\title{
THE EFFECT OF PHOSPHORUS, SULPHUR AND SILICON ON SEGREGATION, SOLIDIFICATION AND MECHANICAL PROPERTIES OF CAST ALLOY 718
}

\author{
J. T. Guo and L. Z. Zhou \\ Institute of Metal Research, Chinese Academy of Sciences, \\ Shenyang 110015, P. R. China
}

\begin{abstract}
Effects of trace elements $\mathrm{P}, \mathrm{S}$ and $\mathrm{Si}$ on the microstructures and mechanical properties in cast alloy 718 have been studied. The results show that $\mathrm{P}, \mathrm{S}$ and $\mathrm{Si}$ promote the segregation of $\mathrm{Nb}$ and formation of Laves phase. It was found that $\mathrm{P}$ and $\mathrm{Si}$ are significant Laves formers, with $\mathrm{P}$ enrichment in the Laves phase of about $1.0 \mathrm{wt} \%$, and Si enrichment of $2.06 \mathrm{wt} \%$. DTA results demonstrate that, as $\mathrm{P}, \mathrm{S}$ contents in the alloys increased, the solidification temperature range increased obviously and the complete solidification was further delayed. On the contrary, Si raised the $\gamma /$ Laves eutectic reaction temperature. Tensile testing indicated that $\mathbf{P}, \mathrm{S}$ and Si had harmful effects on the tensile strength and ductility at RT and $650^{\circ} \mathrm{C}$. When P, S and Si content exceeded $0.013 \mathrm{wt} \%, 0.014 \mathrm{wt} \%, 0.34 \mathrm{wt} \%$ in the alloy, respectively, smooth stress-rupture life and elongations were reduced markedly.
\end{abstract}

\section{Introduction}

One of main problems in as-cast superalloys is the segregation of elements. How to reduce segregation is an important subject. In alloy $718, \mathrm{Nb}$ is a primary element associated with Laves phase and carbides. It strongly segregates to interdendritic regions and promotes the formation of Laves phase, significantly affecting microstructure stability and mechanical properties[1]. Given the same cooling rate, the higher the $\mathrm{Nb}$ content of the alloy, the greater the volume fraction of Laves phase formed in the solidification microstructure. P, S and $\mathrm{Si}$ are impurity elements in superalloys, and are generally regarded as harmful, although little has been reported on the effect of phosphorus on the properties of superalloys. Recent studies showed P determined the
Laves forming behavior of $\mathrm{Nb}$ [2]. R. G. Thompson et al reported that $\mathbf{P}$ segregated uniformly to grain boundary

surfaces when it was present as an intentional additive [3]. In the solidification of alloy IN738, it has been shown that $\mathrm{P}$ increased the segregation of $\mathrm{Al}$ and $\mathrm{Ti}$ to the interdendritic region and the formation of $\gamma / \gamma^{\prime}$ eutectic which reduced stability of alloys[4]. Much attention has focused on sulphur in high-titanium-content alloys. The formation of $\mathrm{Ti}_{2} \mathrm{SC}$ phase could reduce the effect of sulphur to some extent, but in alloy 718 , titanium content is lower (about $1.0 \mathrm{wt}-\%$ ), and more work is necessary on the problem. Silicon may be used as a refining addition during melting, but its presence in the final alloys is considered detrimental and therefore upper limits are usually fixed at a low level in most alloy specifications. This rescarch was aimed at the behavior of trace elements P, S and Si and their effects on the segregation of $\mathrm{Nb}$ during solidification, and the mechanical properties under different $\mathrm{P}, \mathrm{S}$ and Si contents.

\section{Materials and Experimental Proceeds}

First, in order to eliminate the disturbance of other main elements by variation, a low impurity master heat IN718 was melted in vacuum induction furnace with the composition shown in Table 1.

Table 1 Chemical Composition of Master Heat IN718 (wt-\%)

\begin{tabular}{ccccccc}
\hline $\mathrm{C}$ & $\mathrm{Ni}$ & $\mathrm{Cr}$ & $\mathrm{Mo}$ & $\mathrm{Nb}$ & $\mathrm{Ti}$ & $\mathrm{Al}$ \\
\hline 0.031 & 53.19 & 19.07 & 3.04 & 5.20 & 1.05 & 0.53 \\
\hline \multicolumn{8}{c}{} & & & & & \\
\hline $\mathrm{B}$ & $\mathrm{Si}$ & $\mathrm{S}$ & $\mathrm{P}$ & $\mathrm{Mn}$ & $\mathrm{Fe}$ \\
\hline 0.0055 & $<0.05$ & 0.0038 & 0.0008 & $<0.03$ & bal. \\
\hline
\end{tabular}


This heat was divided, remelted and doped with different $\mathrm{P}, \mathrm{S}$ and $\mathrm{Si}$ contents(in the form of Ni-P, FeS and elemental Si, respectively), and subsequently cast by lost wax process to mechanical property specimen ingots. Casting temperature were $1420 \mathrm{C}$, with a shell-model preheat temperature of $900 \mathrm{C}$. P, S and Si contents in the alloys are shown in Table 2.

Table $2 \mathrm{P}, \mathrm{S}$ and Si Contents in the Cast Alloys (wt-\%)

\begin{tabular}{cccc}
\hline Alloy & $\mathrm{P}$ & $\mathrm{S}$ & $\mathrm{Si}$ \\
1 & 0.0008 & 0.0038 & $<0.05$ \\
2 & 0.0055 & 0.0038 & $<0.05$ \\
3 & 0.008 & 0.0038 & $<0.05$ \\
4 & 0.013 & 0.0038 & $<0.05$ \\
5 & 0.032 & 0.0038 & $<0.05$ \\
7 & 0.0008 & 0.014 & $<0.05$ \\
8 & 0.0008 & 0.051 & $<0.05$ \\
9 & 0.0008 & 0.0038 & 0.34 \\
10 & 0.0008 & 0.0038 & 0.95 \\
\hline
\end{tabular}

The above cast specimen ingots after heat treatment were machined into mechanical property specimens with gauge diameter of $5 \mathrm{~mm}$ and gauge length of $25 \mathrm{~mm}$. Tensile properties at room temperature, $650^{\circ} \mathrm{C}$ and $650 \mathrm{C} / 620 \mathrm{MPa}$ rupture life were measured. The heat treatment process was: $1090 \mathrm{C} / \mathrm{lh} / \mathrm{AC}+$ $950^{\circ} \mathrm{C} / \mathrm{th} / \mathrm{AC}+720^{\mathrm{C}} / 8 \mathrm{~h} / \mathrm{FC} 50 \mathrm{C} / \mathrm{h}=620$ C $/ 8 \mathrm{~h} / \mathrm{AC}$. The microstructures were studied by metallographic methods and an electron microprobe was mainly used to observe and measure element segregation. Fracture surfaces were studied by SEM.

The DTA experiments were performed on a Setaram HTC1 800 instrument with a $\alpha-\mathrm{Al}_{2} \mathrm{O}_{3}$ crucible. The DTA cell was calibrated using pure $\mathrm{Ni}(>99.99 \%)$. The precision of this system, using $\mathrm{Pt}-\mathrm{Rh}$ thermocouples, was determined to be better than $5^{\circ} \mathrm{C}$. Specimens weighing $0.3 \mathrm{~g}$ were heated at a fast rate of $100^{\circ} \mathrm{C} / \mathrm{min}$ to $1450^{\circ} \mathrm{C}$ under a flowing helium atmosphere and were held for five minutes before them were cooled at a rate of $15^{\circ} \mathrm{C} / \mathrm{min}$ to $1000^{\circ} \mathrm{C}$. The solidified samples were subsequently cooled at a fast $\operatorname{rate}\left(150^{\circ} \mathrm{C} / \mathrm{min}\right)$ to ambient temperature. The DTA curves were recorded for the temperature range from $1450 \mathrm{C}$ to $1000^{\circ} \mathrm{C}$. Reaction temperatures were determined by finding the temperature at which the DTA curves deviated from the local baseline.

\section{Results}

\section{Microstructure and segregation}

The microstructures of specimens in this study varied with composition, with the $\mathrm{P}, \mathrm{S}$ and $\mathrm{Si}$ contents increasing in the alloy. The amount of Laves phase precipitating from liquid increased, especially for $\mathrm{P}$-doped alloys and Si-doped alloys, giving the alloys a tendency to form well defined dendritic structures(Fig. I).

$\mathrm{P}$ and $\mathrm{Si}$ were heavily enriched in the final solidified $\gamma /$ Laves eutectic phase or Laves phase during solidification process(Figures 2, 3). In the high-P-content alloy $(0.032 w t \% \mathrm{P})$, the $\mathrm{P}$ content in the Laves phase reached $0.982 \mathrm{wt} \%$, about 30 times over average of that doped in the alloy. $\mathrm{Nb}$ content in the Laves phase also increased with the increasing $\mathrm{P}$ content(Table 3 ). In the high-Si-content alloy $(0.95 \% \mathrm{Si})$, the $\mathrm{Si}$ content in the Laves phase reached $2.06 \%$. Table 4 shows that $S$ promoted the segregation of $\mathrm{Nb}$, with the more $\mathrm{S}$ doped in the alloy, the more heavily $\mathrm{Nb}$ segregated in the interdendritic regions and Laves phase.

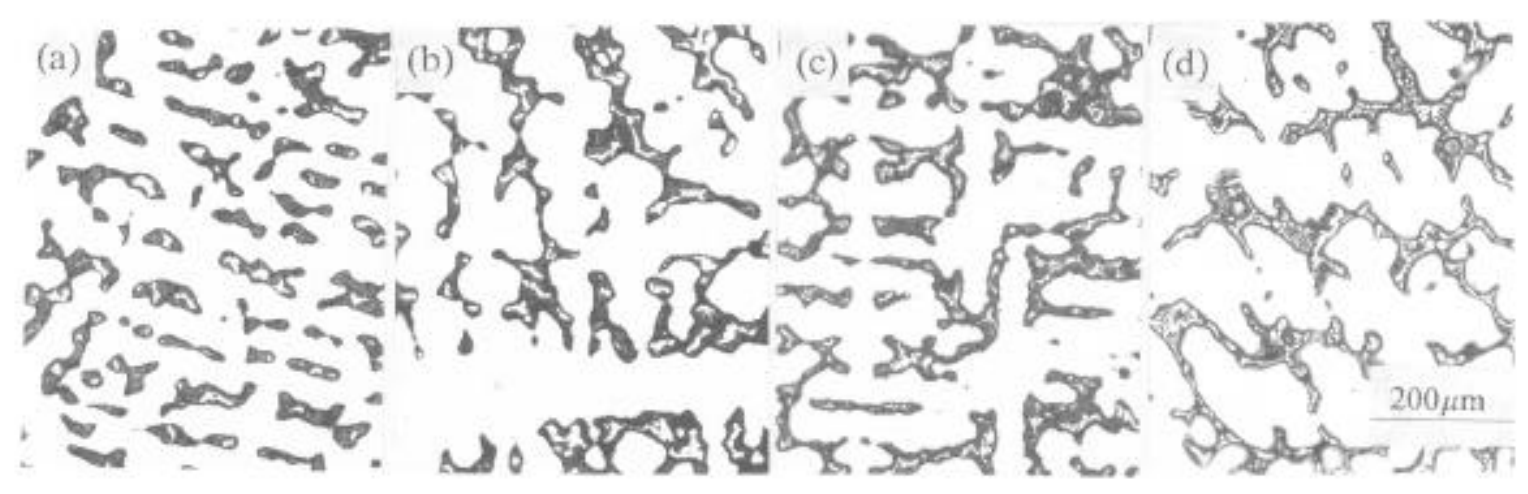

Figure 1: Effect of P, S and Si contents on microstructures of cast alloy 718
(a) No.1, base-alloy
(b) No.5, $0.032 w t \% P$
(c) No.8, 0.051wt $\% \mathrm{~S}$
(d) No. $10,0.95 \mathrm{wt} \% \mathrm{Si}$ 


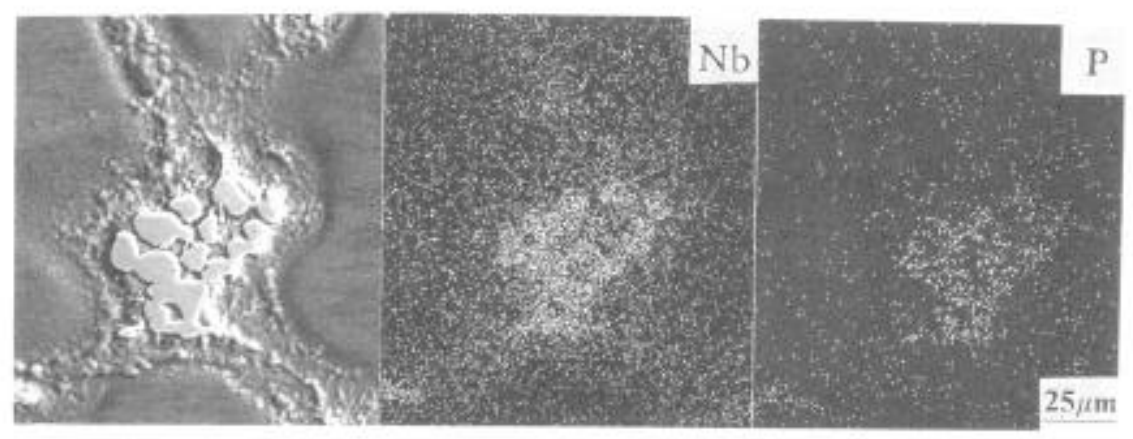

Figure 2: Elemental scanning images in alloy No.5 $(0.032 \mathrm{wt} \% \mathrm{P})$
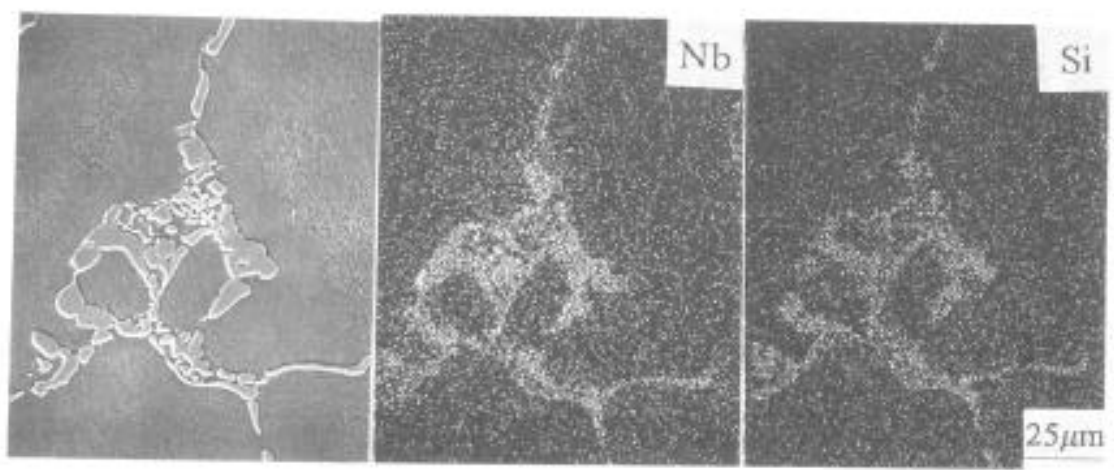

Figure 3: Elemental scanning images in alloy No.10 $(0.95 \mathrm{wt} \% \mathrm{Si})$

Table 3 Average Composition of Laves Phase in the Alloys Doped with P (wt-\%)

\begin{tabular}{cccccccc}
\hline Alloy & $\mathrm{P}$ & $\mathrm{Nb}$ & $\mathrm{Fe}$ & $\mathrm{Ti}$ & $\mathrm{Cr}$ & $\mathrm{Mo}$ & $\mathrm{Ni}$ \\
\hline 1 & 0.036 & 26.619 & 9.957 & 1.608 & 10.649 & 3.558 & bal. \\
3 & 0.243 & 29.904 & 9.455 & 1.927 & 10.059 & 3.792 & bal. \\
5 & 0.982 & 30.886 & 11.391 & 0.950 & 12.818 & 4.738 & bal. \\
\hline
\end{tabular}

Table 4 The Analysis of $\mathrm{Nb}$ Segregation in Alloys Doped with $\mathrm{S}$

\begin{tabular}{ccccc}
\hline $\begin{array}{c}\text { Alloy } \\
\text { No. }\end{array}$ & $\begin{array}{c}\text { W } \\
\text { Wt } \%\end{array}$ & $\begin{array}{c}\text { Dendritic } \\
\text { Core }\end{array}$ & $\begin{array}{c}\text { Interdendritic } \\
\text { Regions }\end{array}$ & Laves \\
\hline 1 & 0.0038 & 3.16 & 5.00 & 15.98 \\
7 & 0.014 & 1.71 & 5.70 & 20.88 \\
8 & 0.051 & 1.55 & 6.36 & 21.68 \\
\hline
\end{tabular}

DTA

The DTA cooling curves of cast alloy 718 with different $\mathrm{P}, \mathrm{S}$ and Si contents have been determined. The data obtained from the DTA cooling curves were tabulated in table 5. It was found that $\mathrm{P}$ or $\mathrm{S}$ had little effect on the incipient solidification temperature $\left(\gamma_{\text {liquidus }}\right)$ and solidification temperature of MC, while Si obviously reduced $\gamma_{\text {liquidus. }}$ The $\gamma /$ Laves eutectic reaction temperatures varied with $\mathrm{P}, \mathrm{S}$ and Si contents in the alloys. With increasing of $\mathrm{P}$ and $\mathrm{S}$ contents, the final solidificatio $\mathrm{n}(\gamma /$ Laves eutectic reaction) temperature was reduced and the solidification temperature range increased. In contrast, Si raised the $\gamma /$ Laves eutectic reaction temperature and reduced the solidification temperature range. The S-doped alloy solidified at following sequence: $\mathrm{L}=\mathrm{L}+\gamma=\mathrm{L}+\gamma+$ Sulphide $>\mathrm{L}+\gamma+$ Sulphide + MC $-\gamma+$ Sulphide $+\mathrm{MC}+\gamma /$ Laves(Eutectic). 
Table 5 Characteristic Temperatures Obtained from the DTA Cooling Curves

\begin{tabular}{cccccc}
\hline Alloy & $y_{\text {liquidus }}$ & MC & Sulphide & Eutectic & $\Delta \mathrm{T}^{\text {l) }}$ \\
\hline 1 & 1329 & 1229 & - & 1157 & 172 \\
3 & 1321 & 1225 & - & 1139 & 182 \\
5 & 1321 & 1225 & - & 1129 & 192 \\
8 & 1329 & 1225 & 1200 & 1143 & 186 \\
10 & 1307 & - & - & 1186 & 121 \\
\hline
\end{tabular}

1) $\triangle T$ Solidification temperature range ( $C$ )

\section{Mechanical properties}

Tensile testing at room temperature and $650^{\circ} \mathrm{C}$ with different $\mathrm{P}, \mathrm{S}$ and Si contents was conducted. The results showed that $\mathrm{P}, \mathrm{S}$ and $\mathrm{Si}$ were harmful to tensile strengthand reduced ductility in the alloys. The smooth stress-rupture life and elongation with different $P, S$ and Si contents have also been determined at the conditions of $650^{\circ} \mathrm{C} / 620 \mathrm{MPa}$. It showed that smooth stress-rupture life and elongation were reduced with increasing of $\mathrm{P}, \mathrm{S}$ and Si contents. When phosphorus, sulphur, silicon contents in the alloys are in excess of $0.013 \mathrm{wt} \%$, $0.014 \%, 0.34 \%$, respectively, life and elongation dropped rapidly.
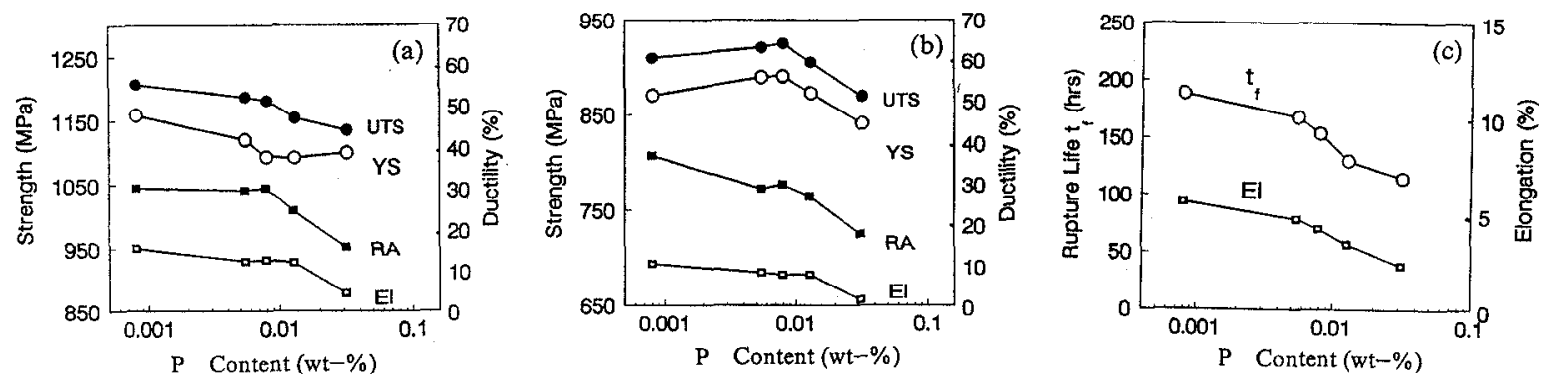

Figurc 4: Effect of $P$ content on mechanical properties of cast alloy 718

(a) at room temperature (b) at $650^{\circ} \mathrm{C}$ (c) at $650^{\circ} \mathrm{C} / 620 \mathrm{MPa}$

Table 6 Effect of S Content on Tensile and Rupture Properties of Cast Alloy 718

\begin{tabular}{cccccccccccc}
\hline Alloy & \multicolumn{1}{c}{ S } & \multicolumn{2}{c}{ YS, MPa } & \multicolumn{2}{c}{ UTS, MPa } & \multicolumn{2}{c}{ El, \% } & \multicolumn{2}{c}{ RA, \% } & \multicolumn{2}{c}{$\mathrm{SR}^{1)}$} \\
No. & Wt-\% & RT & $650 \mathrm{C}$ & RT & $650^{\circ} \mathrm{C}$ & RT & $650^{\circ} \mathrm{C}$ & RT & $650^{\circ} \mathrm{C}$ & Life,h & El,\% \\
\hline 1 & 0.0038 & 1159 & 870 & 1207 & 910 & 16.0 & 10.8 & 30.6 & 37.0 & 188.5 & 5.7 \\
7 & 0.014 & 1102 & 823 & 1164 & 864 & 8.7 & 8.7 & 24.0 & 36.0 & 78.0 & 3.6 \\
8 & 0.051 & 1040 & 808 & 1105 & 841 & 7.3 & 8.2 & 21.0 & 21.5 & 19.0 & 2.0 \\
\hline
\end{tabular}

Table 7 Effect of Si Content on Tensile and Rupture Propertics of Cast Alloy 718

\begin{tabular}{ccccccccccccc}
\hline Alloy & $\mathrm{Si}$ & \multicolumn{2}{c}{$\mathrm{YS}, \mathrm{MPa}$} & \multicolumn{2}{c}{$\mathrm{UTS}, \mathrm{MPa}$} & \multicolumn{2}{c}{ El, \% } & \multicolumn{2}{c}{ RA, \% } & \multicolumn{2}{c}{ SR } \\
No. & Wt-\% & RT & $650 \mathrm{C}$ & RT & $650 \mathrm{C}$ & RT & $650 \mathrm{C}$ & RT & $650 \mathrm{C}$ & Life,h & El,\% \\
\hline 1 & $<0.05$ & 1159 & 870 & 1207 & 910 & 16.0 & 10.8 & 30.6 & 37.0 & 188.5 & 5.7 \\
9 & 0.34 & 1100 & 878 & 1179 & 889 & 8.7 & 6.7 & 24.0 & 32.0 & 136.5 & 4.2 \\
10 & 0.95 & 982 & 795 & 988 & 858 & 2.0 & 1.8 & 2.6 & 7.8 & 57.0 & 2.4 \\
\hline
\end{tabular}




\section{Discussion}

The alloy IN718 solidifies in the following sequence: $\mathrm{L}$ * $\mathrm{L}+\gamma>\mathrm{L}+\gamma+\mathrm{MC}>\gamma+\mathrm{MC}+\gamma /$ Laves. This is verified by DTA curves of the alloys. The solubility of $\mathrm{P}, \mathrm{S}, \mathrm{Si}$ in nickel is very low with a maximum of about $0.3 \mathrm{wt} \%[5]$, $0.005 \mathrm{wt} \%[6],<0.5 \mathrm{wt} \%$, respectively, so that $\mathrm{P}, \mathrm{S}$ and $\mathrm{Si}$ should mostly enrich in the final solidification regions and result in heavily segregation. The higher the $\mathrm{P}, \mathrm{S}$ and Si contents doped in the alloys, the more they would be enriched in interdendritic areas.

The segregation of $\mathrm{P}, \mathrm{S}$ and $\mathrm{Si}$ elements promotes the segregation of $\mathrm{Nb}$, this could be scen from above. $\mathrm{Nb}$ is a primary element in the Laves phase and the Laves phase is generally accepted to be the form $(\mathrm{Ni}, \mathrm{Fe}$, $\mathrm{Cr})_{2}(\mathrm{Nb}, \mathrm{Mo}, \mathrm{Ti})$ [1]. Therefore, the more $\mathrm{Nb}$ segregated in interdendritic regions, the higher volume fraction of Laves formed.

The effects of $\mathrm{P}, \mathrm{S}$ and $\mathrm{Si}$ on the mechanical properties mainly lie in the following: $\mathrm{P}, \mathrm{S}$ and $\mathrm{Si}$ segregate in the final regions, and promote the segregation of $\mathrm{Nb}$ to form Laves phase. Laves phase has been generally accepted as being deleterious to the mechanical properties of the alloy. It was associated with reduced tensile strength and ductility, because it is a brittle phase, even at elevated temperature, it is likely to act as a preferred crack initiation and propagation site [1]. The greater volume fraction of laves phase in the alloys presents a higher probability for the crack to grow through the brittle phase or $\gamma /$ Laves interfaces. In addition, Laves consumes large amounts of $\mathrm{Nb}$ depleting the matrix of $\mathrm{Nb}$ which is the principal hardening element. Stress-rupture fracture surfaces were studied by SEM. It was found that the fracture surfaces included grain boundary, eutectic interface, $\gamma / \mathrm{MC}$ interface. With the increasing of $\mathrm{P}, \mathrm{S}$ and $\mathrm{Si}$ contents in the alloys, they showed greater tendency to brittle fracture. That would explain why the high $\mathrm{P}, \mathrm{S}$ and $\mathrm{Si}$ alloys with gross Laves showed reduced rupture strength and ductility.

\section{Conclusions}

$1 \mathrm{P}, \mathrm{S}$ and $\mathrm{Si}$ are enriched mostly in the final solidification regions, and $\mathrm{P}, \mathrm{Si}$ become formers of Laves phase.

$2 \mathrm{P}, \mathrm{S}$ and $\mathrm{Si}$ promote the segregation of $\mathrm{Nb}$ and the formation of Laves phase.
3 The solidification temperature range is widened with increasing of $\mathrm{P}$ and $\mathrm{S}$ contents in the alloy. On the contrary, Si raised $\gamma /$ Laves eutectic reaction temperature and reduces solidification temperature range.

4 Tensile strength and ductility at room temperature and $650^{\circ} \mathrm{C}$ are reduced with increasing of $\mathrm{P}, \mathrm{S}$ and $\mathrm{Si}$ contents in the alloy.

5 Smooth stress-rupture life and elongations are reduced obviously markedly with increasing of $\mathrm{P}, \mathrm{S}$ and $\mathrm{Si}$ contents in the alloy.

\section{Acknowledgments}

The authors wish to acknowledge Prof.Tresa Pollock and Radavich for helpful comments concerning this manuscript. The portions of the research were funded by the National Science Foundation.

\section{Reference}

1. J. J. Schirra, R. h. Caless, R. W. Hatana, "The Effect of Laves phase on the Mechanical Properties of Wrought and Cast + HIP Inconel 718"(Paper presented at the International Symposium on the Metallurgy and Application of Superalloys 718, 625 and Various Derivatives, Pittsburgh, Pennsylvania, 23-26 June 1991),375

2. C. Chen, R. G. Thompson and D. W. Davis, "A Study of Effects Phosphorus, Sulfur, Boron and Carbon on Carbide Formation in Alloy 718"(Paper presented at the International Symposium on the Metallurgy and Application of Superalloys 718, 625 and Various Derivatives, Pittsburgh, Pennsylvania, 23-26 June 1991), 81.

3. R. G. Thompson, M. C. Koopman, and B. H. King, "Grain Boundary Chemistry of Alloy 718-Type Alloys"(Paper presented at the International Symposium on the Metallurgy and Application of Superalloys 718, 625 and Various Derivatives, Pittsburgh, Pennsylvania, 23-26 June 1991), 53-65.

4. Y. X. Zhu, "The Effect of $P$ on the Cast M38(IN738) Alloy" ( Report No.85147, Institute of

Metal Research, Chinese Academy of Sciences, 1985).

5. R. T. Holt, W. Wallace, "Impurities and Trace Elements in Nickel-base Superalloys," International Metals Reviews, 21(1976),1-24.

6. Taylor Lyman, ed.,Metals Handbook(Prepared under the direction of the Metals Handbook Committee. 1948), ASM Published, 1232. 